\title{
ANÁLISIS
}

\section{The Trans-Pacific Partnership: Understanding the Economic Impact for Mexico and Canada}

DOI: $10.32870 /$ mycp.v5i13.498

Juan Salvador Navarro Estrada ${ }^{1}$

\begin{abstract}
The Trans-Pacific Partnership is a potential Free Trade Agreement (FTA) at an advanced stage of negotiation. The TPP is composed of 12 countries from the Asia-Pacific region: New Zealand, Peru, Vietnam, Australia, Singapore, Brunei, Malaysia, Mexico, Chile, Canada, Japan and the United States. The objective of these nations is to create a cutting-edge FTA which solves traditional and non-traditional trade issues which are affecting global commerce and investments.

Nonetheless, there is a lack of knowledge and understanding of people, including business people with regard to the economic impact that the Trans-Pacific Partnership (TPP) might generate for participating nations such as Mexico and Canada. Thus, this research paper presents information which was collected and analyzed not only to make aware Canadian and Mexican

Artículo recibido el 4 de junio de 2015 y dictaminado el 21 de agosto de 2015.

1. President of the Society of Mexican Talent in British Columbia, Canada and an entrepreneur with vast experience in business, finance, economics and education. He is a former economist from the Central Bank of Mexico and former business professor of Tec de Monterrey and Universidad Panamericana. Member of the Canadian International Council and former member of the Mexican Institute of Executives in Finance (IMEF). Pickford Road 2974-A, Victoria, British Columbia, Canada V9B2K7. E-mail: juan.navarro@redtalentosbc.com
\end{abstract}


business people about the relevance of the TPP, but also to encourage them to find synergies and collaborations between them. Analysis was based on secondary research, collecting information through multiple secondary data sources to provide different perspectives.

The research drew attention to the fact that the TPP region might become one of the most relevant trade regions around the globe, because it would represent an attractive market of more than 800 million consumers, representing about 40\% of the Global GDP (Dawson \& Bartucci, 2013: 2-4). Further investigations revealed that the economic impact of the TPP for all 12 nations would be positive and based on trade creation. It is estimated that by 2025, the TPP would produce extra income in the world trade of 295 billion USD (Petri, Plummer \& Zhai, 2012: 85). In the particular case of Canada and Mexico, economists have pointed out that by 2025, Mexico could receive substantial benefits from the TPP, gaining 21 billion USD in additional income, whereas Canada would also gain extra income, about 9.9 billion USD (Petri et al., 2012: 40-44).

Finally, this research paper states five recommendations for Canadian and Mexican business people to increase their knowledge and understanding of the TPP and they contribute to get the benefits when this FTA is in force.

Keywords: Trans-Pacific Partnership, free trade agreement, North America, trade and investment, international economics.

\section{El ACuERdo de Asociación TRANSPACífico: ENTENDIENDO EL IMPACTO ECONÓMICO PARA MÉXICO Y CANADÁ}

\section{Resumen}

El Acuerdo de Asociación Transpacífico (TPP) es un potencial acuerdo de libre comercio (TLC) que se encuentra en una etapa avanzada de negociación. El TPP está integrado por 12 países de la región Asia-Pacífico: Nueva Zelanda, Perú, Vietnam, Australia, Singapur, Brunei, Malasia, México, Chile, Canadá, Japón

y Estados Unidos. El objetivo de estas naciones es crear un acuerdo de libre comercio de vanguardia que resuelva cuestiones comerciales tradicionales y no tradicionales que están afectando el comercio y las inversiones a nivel mundial.

No obstante la relevancia del TPP, hay una falta de conocimiento y comprensión entre la población, incluida la gente de negocios en relación con el impacto económico que este acuerdo comercial podría generar para los 
países participantes como México y Canadá. De tal manera, este trabajo de investigación presenta información no sólo para hacer conscientes a los empresarios canadienses y mexicanos sobre la relevancia del TPP, sino también para animarles a encontrar sinergias y colaboraciones entre ellos.

La investigación puso de relieve que el TPP podría convertirse en una de las regiones comerciales más relevantes de todo el mundo, ya que representaría un atractivo mercado compuesto por una población de más de 800 millones de consumidores y que representa cerca de $40 \%$ del PIB mundial (Dawson y Bartucci, 2013: 2-4). Otras investigaciones revelaron que el impacto económico del TPP para las 12 naciones participantes sería positivo, basado en la creación de comercio. Se estima que para el año 2025 el TPP produciría un ingreso mundial adicional de 295 billones de dólares (Petri, Plummer y Zhai, 2012: 85). En el caso particular de Canadá y México, los economistas han señalado que en el año 2025 México podría recibir beneficios sustanciales a través del TPP, ganando 21 mil millones de dólares en ingresos adicionales, mientras que Canadá también ganaría un ingreso extra equivalente a 9,900 millones de dólares (Petri et al., 2012: 40-44).

Finalmente, en esta investigación se establecen cinco recomendaciones para que empresarios canadienses y mexicanos sigan incrementando su conocimiento y comprensión sobre el TPP y contribuyan a obtener los beneficios de este acuerdo comercial cuando éste entre en vigor.

Keywords: Acuerdo de Asociación Transpacífico, tratado de libre comercio, Norteamérica, comercio e inversión, economía internacional.

\section{Introduction}

While Free Trade Agreements (FTAs) are a common term in international economics, understanding FTAs and their impact are not always clear. Deardorff (2014) defined a FTA as a trade pact in which "the member countries reduce to zero all tariffs on imports from other member countries of all, or almost all, products" (p. 3). Petri et al. (2012) supported the creation of FTAs because they liberalize markets and amplify trade (p. 36). Nonetheless, Deardorff (2014) recognized that participants of FTAs often put into the agreements clauses to protect some industries or products from competition under the argument of "sensitive sectors" and this decision has negative impacts (p. 3).

Currently, one of the most important FTAs being negotiated around the globe is the Trans-Pacific Partnership (TPP). This potential FTA, which is at 
an advanced stage of negotiation, is composed of 12 nations (TPP12): New Zealand, Peru, Vietnam, Australia, Singapore, Brunei, Malaysia, Mexico, Chile, Canada, Japan and the United States (Fergusson, McMinimy \& Williams, 2014: 1). From the 12 TPP nations, of particular interest in this research paper are Canada and Mexico, two nations with a trade relationship through NAFTA for more than 20 years. Currently, these two nations "are each other's third largest trading partners" (Government of Canada, 2014, para. 4). As well, Mexico is second as the auto parts supplier to Canada, and Canada is in seventh place in terms of foreign direct investment in Mexico (Promexico, 2014). According to the Ministry of Foreign Affairs, Trade and Development Canada, Mexico is "a trusted and long-term partner of choice for Canada [...] and is a reliable supporter of regional and global solutions" (2014b).

Notwithstanding this data about commerce between Mexico and Canada, according to Beatty \& Rozental (2012), these two nations "should realize that despite the growth in bilateral trade and investment, they may be leaving economic opportunities lying on the table" (p. 7). Beatty \& Rozental (2012) claimed that the TPP could be a good opportunity to "work together and maximize benefits" (p. 7). Dawson (2014) noted that "Canadians have been slow to recognize the opportunities Mexico provides" (p. 3); and these words could also be applied to Mexicans about Canada.

Mexico and Canada decided to join the TPP agreement almost at the same time and faced "similar challenges and opportunities" (Stephens \& Navarro, 2014: 1). However, it seems that there are people, including business people in these two countries who are not aware of the existence of the TPP, its objectives and scope, and its positive economic impact. So, this paper aims to offer valuable information to increase the understanding and knowledge of Mexican and Canadian business people about the TTP and encourage them to find synergies and collaborations.

This research is structured in three main sections. The first section, the literature review, summarizes the research findings, presenting the context about the TPP and data which contributes to analyzing its economic impact. In the second section, the analysis, the principal findings are analyzed and discussed. The third section, the recommendations section, outlines seven actions that Mexican and Canadian businesses should carry out to continue understanding the TPP and create synergies between them. 


\section{Literature Review}

This section provides information from secondary research, and lays the basis for subsequent analysis and discussion.

\subsection{The Trans-Pacific Partnership (TPP)}

Petri \& Plummer (2012) defined the Trans-Pacific Partnership as a trade pact which could change the way international trade and investments are being conducted not only in the Asia-Pacific region, but also around the entire globe; and they highlighted that the TPP could provide new engines to boost the economic growth for all the participant nations (p. 1-2).

\subsubsection{The TPP: Background and current status}

The origin of the TPP is the Trans-Pacific Strategic Economic Partnership agreement, also known as the "P4" which was started by New Zealand, Chile and Singapore in 2003, and Brunei joined in 2005, with the P4 enforced in 2006 (Fergusson et al., 2014: 1). One goal of the P4 was attracting new members from APEC nations, and they achieved it when Peru, the United States, Vietnam and Australia asked to join the P4 in September 2008 (Schott et al., 2013: 5). The formal talks to negotiate the TPP started in March of 2010, and after a few months, Malaysia expressed its interest to become a member (Schott et al., 2013: 5). In 2012, Mexico and Canada asked for their admission and were accepted, and they joined together during the $15^{\text {th }}$ round in December 2012 (Fergusson et al., 2014: 3-41). Subsequently, in April 2013 Japan received approval to become a member of the TPP (Elms, 2013: 380).

The negotiations of the TPP have been celebrated in different kinds of meetings: some of these are the TPP meetings of leaders and ministers, the meetings of chief negotiators, the TPP ministerial meetings, the meeting of TPP Officials and the negotiating rounds. About 19 negotiating rounds to date have been carried out (Foreign Affairs, Trade and Development Canada [FATDC], 2014a). The last TPP officials' meeting celebrated this year was in Maryland, us from April 23 to 26 of the (Australian Government, 2015) where negotiating countries advanced in "resolving differences on market access and trade rules to be included in the TPP" (para. 1). There was another meeting of TPP officials scheduled to be celebrated in Guam, Us from May 15 
to 25 , where there was high expectations to reach the final text, but it was postponed presumably because "it is uncertain whether the U. S. Congress will approve legislation on Trade Promotion Authority" (The Japan Times, 2015). This approval of the us Congress would give President Obama fasttrack authority to negotiate trade agreements such as the TPP.

\subsubsection{Countries negotiating the TPP}

The TPP is a Free Trade Agreement that currently is being negotiated by a group of twelve nations (TPP12): New Zealand, Peru, Vietnam, Australia, Singapore, Brunei, Malaysia, Mexico, Chile, Canada, Japan and the United States. These 12 countries are quite diverse from each other, either in indicators of development or economics.

Considering the GDP per capita among nations of TPP12, United States has the highest with 56,421 USD, while the lowest one is Vietnam with 2,233 USD (see table 1); however, the participation of Vietnam is justified not only because of the size of its population, but also by its dynamic economy which grew "7.1 percent on average from 2001 to 2011" (Schott et al., 2013: 6). According to Schott et al. (2013) these kinds of differences are part of the richness of the potential agreement:

The TPP comprises countries that are both rich and poor and large and small; despite this diversity, however, the countries engaged in the talks are "likeminded" in their pursuit of a comprehensive trade accord that covers both traditional and new issues affecting global trade and investment (p. 61).

\subsubsection{Objectives and scope}

Fergusson et al. (2014) stated that the objectives and scope of the TPP were raised during the APEC meeting in 2011. At this meeting, the leaders of the TPP nations stated five key areas to guide negotiations: comprehensive market access, cross cutting trade issues, fully regional trade pact, living agreement, and new trade challenges. The nine countries negotiating the agreement at that time defined the TPP as " $a$ comprehensive, next-generation regional agreement that liberalizes trade and investment and addresses new and traditional trade issues and 21st-century challenges'” (p. 3).

Schott et al. (2013) pointed out that the main objective of TPP countries is

"to create a trade regime that is state of the art and sets a precedent for future 


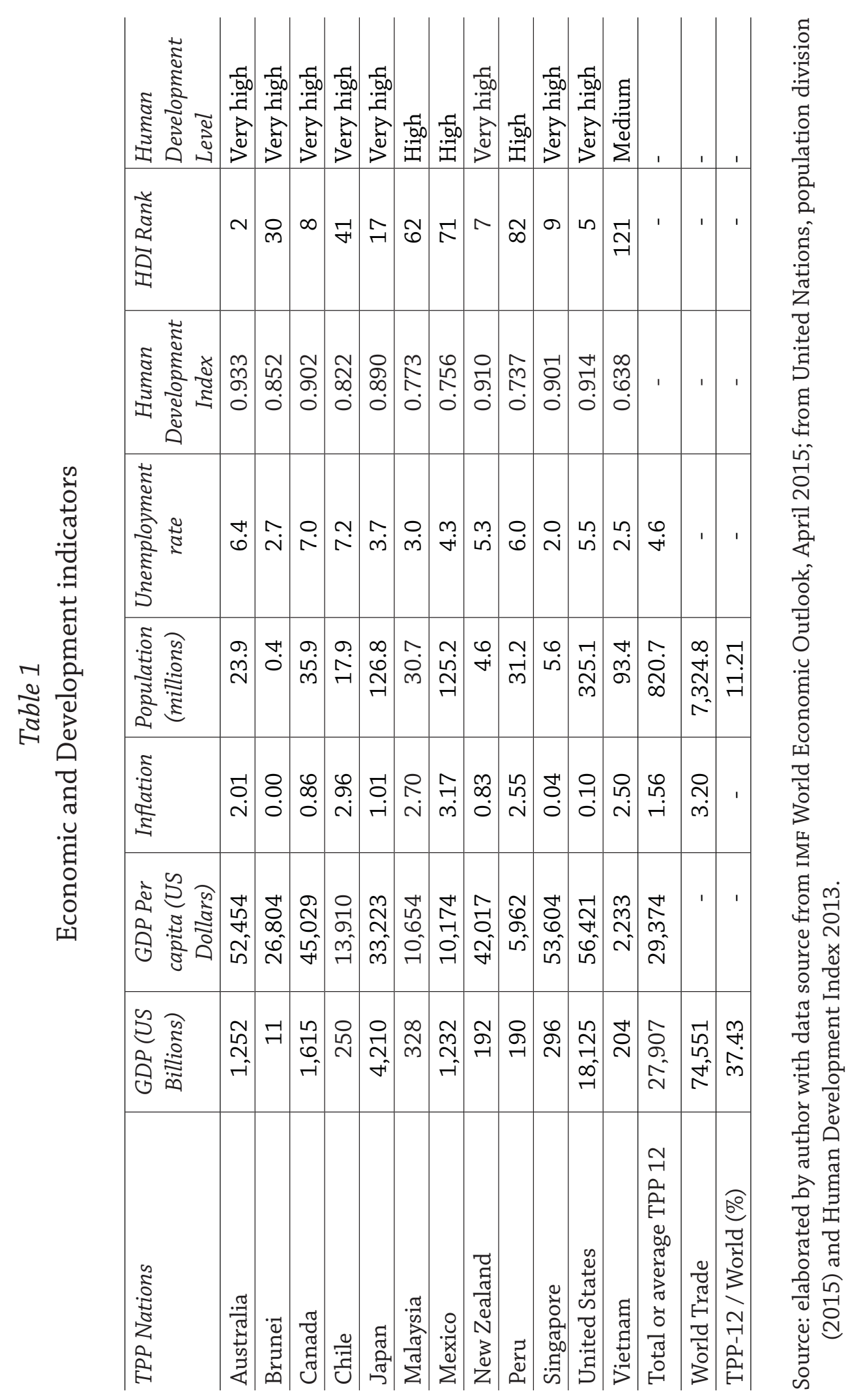


trade negotiations" (p. 12). Additionally, Schott et al. (2013) stated that the TPP is looking to discuss all the issues negatively affecting current FTAs and to solve these, as well to build "a new trade rulebook" which includes both traditional and non traditional topics (p. 12). Guoqiang \& Petri (2014) considered that one of the most valuable contributions from TPP members is that they aim to build a "living agreement", which means "the TPP would never be out of date" (p. 14). Pham et al. (2014) pointed out that the TPP will create a great environment for innovation through the promotion of standards in areas such as "copyrights, patents, regulatory data safeguards, trademarks, and trade secrets" (p. 3).

For the United States, one of the most important players at the negotiation table, the TPP has objectives for not only establishing rules on areas like sOEs, labour, the environment, competition and more, but also for "bringing traditional trade principals into the digital era [...] to bolster a free and open Internet, the free flow of data, and the capacity of small and medium-sized businesses to integrate themselves efficiently into the global economy" (United States Trade Representative [USTR], 2014, para. 17-19).

Fergusson et al. (2014: 16) identified a list of 30 topics to make reality the objectives of the TPP and said that each of them could be part of one chapter in the final text of this FTA.

Table 2

\section{Negotiating Topics in TPP (Potential Chapters)}

\begin{tabular}{l|l}
\hline Goods Market Access & Competition / State-owned Enterprises \\
Agriculture Market Access & Trade Remedies \\
Textiles and Apparel & Transparency \\
Customs / Trade Faciliation & Labor \\
Rules of Origen & Environment \\
Technical Barriers to Trade & Cooperation and Capacity Building \\
Sanitary and Phytosanary Standers & Regulatory Coherence \\
Services & Business Facilitation and Competitiveness \\
Investment & Development \\
Financial Services & Small-and Medium Size Enterprises \\
Telecommunications & Institutional Chapters \\
E-Commerce / Digital Trade & Dispute Settlement \\
Temporary Entry & Living Agreement \\
Intellectual Property Rights & Exceptions \\
Government Procurement & Definitions \\
\hline
\end{tabular}

Source: Fergusson et al., 2014: 16. 


\subsubsection{Canada and Mexico in the TPP}

Schott et al. (2013) reported that Mexico was invited to become a member of the TPP on June 18, 2012, and Canada just one day after (p. 41). Mexico and Canada had their first appearance in negotiating rounds on the $15^{\text {th }}$ in Auckland, New Zealand in December 2012 (Australian Government, 2012). Schott et al. (2013) highlighted that for both Mexico and Canada, it was imperative to become a member of the TPP for three reasons: to prevent "losing market share in key Asian economies", to keep their competitiveness in the North American region, and to actualize NAFTA (p. 42). Stephens \& Navarro (2014) affirmed that for both nations, "the TPP offers the prospect of foothold in Asia and in being on the ground floor as the trade architecture of the region is constructed" (p. 2).

The governments of Canada and Mexico have justified joining the TPP by saying that it would benefit their economies. For example, the Canadian government trusts that the TPP will move its economy forward by creating jobs, promoting welfare and building prosperity (FATDC, 2012, para. 2). Furthermore, the Minister of International Trade of Canada, Ed Fast, declared that "TPP negotiations are part of our ambitious pro-trade, pro-export plan to create jobs and opportunities for Canadian workers and businesses targeting the dynamic and fast-growing Asia-Pacific region" (FATDC, 2014a). Specifically, Foreign Affairs, Trade and Development Canada (2013) noted that some of the sectors that the TPP would benefit most are the financial services sector which includes insurance companies and banks; the chemical and plastics sector, the advanced manufacturing sector which includes industrial machinery and information technology, the fish and seafood sector, the agricultural sector and the wood sector and related industries (para. 6-10).

Researchers also supported the integration of Canada in the TPP negotiations. For instance, Schott et al. (2013) pointed out that Canada had to be part of the TPP because it would make FTAs a reality with nations which they don't have any FTAs, such as Japan and Singapore (p. 42). Further, Dawson (2012) encouraged the participation of Canada in the TPP because it would generate new opportunities for Canadian businesses, expanding their presence in "the developed markets of Australia and New Zealand [...] to economically vigorous emerging markets such as Singapore, Malaysia and Vietnam, and re-engage with current FTA partners Chile, Peru and the United States" (2012: 5). 
About Mexico, its government said that they entered the TPP because it would allow Mexico to access six new markets, which are Vietnam, Malaysia, Australia, New Zealand, Singapore and Brunei, to increase its attractiveness and to retain and attract more foreign investments (Secretaría de Economía, 2014). Schott et al. (2013) supported Mexico joining the TPP not only because it would accelerate and diversify its economy through the penetration in dynamic new markets, but also because it would strengthen a trade relationship with nations that has been growing exponentially (pp. 44-45). For instance, Mexican exports during the last decade grew 13 percent to Singapore and New Zealand, and 23 percent to Australia (Schott et al., 2013: 45).

De Rosenzweig (2012) noted that the TPP will not only help prevent erosion of tariff preferences of Mexican products in the US, but also will provide an opportunity to consolidate Mexico as a strategic node in global value chains in Asia and North America, raising the proportion of Mexican added value incorporated in exports of goods to these regions. De Rosenzweig (2012) mentioned that this is a unique opportunity for Mexico to deepen its relationship with Asia-Pacific markets as well as to reset NAFTA (para. 33-34). Some economic sectors that would benefit through the TPP in Mexico are the automotive, aerospace, mining, services and agriculture which includes agro industrial products (De Rosenzweig, 2012, para. 28-29).

\subsubsection{FTAs among TPP members}

The TPP members are not unfamiliar with each other; many of them have already, in effect, signed, under negotiation or under consideration a large number of bilateral and regional FTAs. For instance, Canada has FTAs in force with four countries of the TPP12: Chile, Mexico, United States and Peru, whereas Mexico has FTAs in force with five TPP nations: Chile, Peru, United States, Canada and Japan (Schott et al., 2013: 14-15).

\subsubsection{Issues in TPP negotiations}

Guoqiang \& Petri (2014) presented a list of six areas with the most contentious issues that TPP negotiators are dealing with and some views from the position of some TPP participants about these issues (pp. 29-30). These six issues are shown in the next table. 


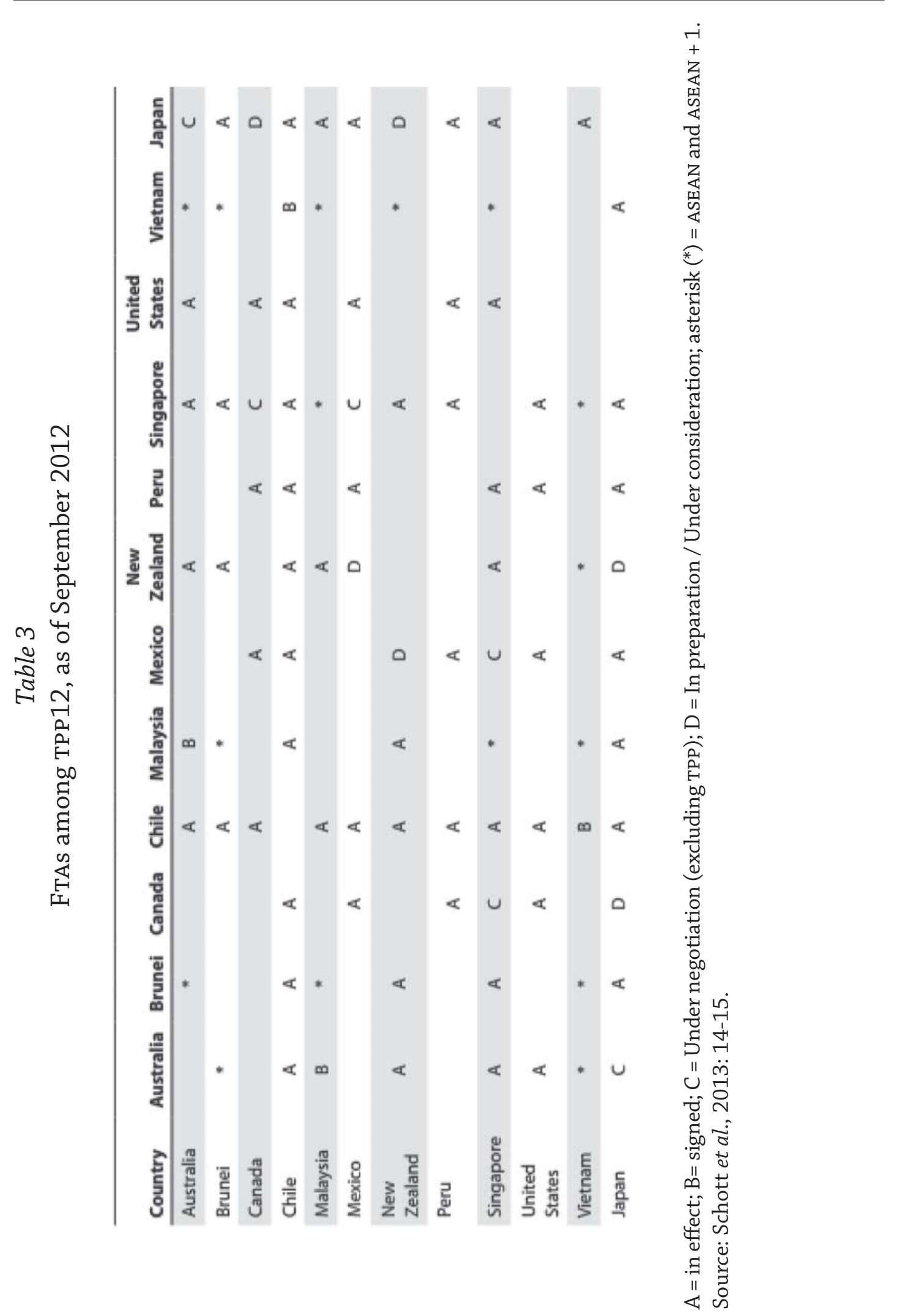


Table 4

Contentious Issues in TPP Negotiations as of June 2014

\begin{tabular}{l|l|l}
\hline Areas & $\begin{array}{l}\text { Economies most } \\
\text { involved }\end{array}$ & Issues \\
\hline Market access & US vs. JPN & $\begin{array}{l}\text { The US claims that Japan's tariffs on agricultural prod- } \\
\text { ucts should be substantiatlly reduced. Japan claims that } \\
\text { auto tariffs in the US should be eliminated }\end{array}$ \\
\hline $\begin{array}{l}\text { Intellectual } \\
\text { property } \\
\text { rights }\end{array}$ & $\begin{array}{l}\text { US (JPN) vs. } \\
\text { MAS \& VIE }\end{array}$ & $\begin{array}{l}\text { The US claims that data for pharmaceutical products and } \\
\text { copyrights (for novels, movies, music, etc.) should be } \\
\text { protected for a long period. While Malaysia and others } \\
\text { claim that such protection should be for a short period. }\end{array}$ \\
\hline $\begin{array}{l}\text { Competition } \\
\text { policy }\end{array}$ & $\begin{array}{l}\text { US (AUS, JPN) } \\
\text { vs. MAS, VIE, } \\
\text { BRU }\end{array}$ & $\begin{array}{l}\text { The US claims that policies that favor SOEs (such as sub- } \\
\text { sidies) should be abolished to establish a level playing } \\
\text { field against private firms, while Malaysia and others ar- } \\
\text { gue against such a claim. }\end{array}$ \\
\hline $\begin{array}{l}\text { Government } \\
\text { procurement }\end{array}$ & $\begin{array}{l}\text { SIN (US, JPN) } \\
\text { vs. MAS, VIE, } \\
\text { BRU }\end{array}$ & $\begin{array}{l}\text { Singapore and others argue that government procure- } \\
\text { ment should be opened to foreign firms, while Malaysia } \\
\text { and others are reluctant. }\end{array}$ \\
\hline Investment & $\begin{array}{l}\text { US (JPN) vs. } \\
\text { AUS (NZL, MAS) }\end{array}$ & $\begin{array}{l}\text { The US and others argue that an investor-state dispute } \\
\text { settlement (ISDS) system should be introduced. While } \\
\text { Australia and others are against it. }\end{array}$ \\
\hline Environment & $\begin{array}{l}\text { US (CAN, JPN) } \\
\text { vs. VIE, MAS }\end{array}$ & $\begin{array}{l}\text { The US and others argue that environmental standards } \\
\text { for firm activity should be improved, while Vietnam and } \\
\text { others are reluctant. }\end{array}$ \\
\hline
\end{tabular}

AUS = Australia; BRU = Brunei; JPN = Japan; MAS = Malaysia; NZL = New Zealand; SIN = Singapore; US = United States; VIE = Vietnam.

Source: Guoqiang \& Petri, 2014: 29-30.

About the particular issues that Mexico and Canada might be concerned and dealing with, Mexico is dealing with special interest, issues in products such as sugar, beef, dairy, footwear and textiles (Schott et al., 2013: 45). On the other hand, Schott et al. (2013) reported that TPP partners expect that Canada will implement important reforms in its agriculture sector, decreasing tariffs significantly and including changes about the supply management of products such as dairy (p. 42). The reasons behind these demands are that TPP members such as Australia, New Zealand and the United States have companies in the dairy industry which have "major export interests" (Rude \& An, 2013: 404). In this regard, Schott et al. (2013) opined that if the dairy industry is liberalized in the TPP, Canada could find good opportunities as an exporter to the Japanese market and others in Asia (p. 22) (see table 5). 
Table 5

Trade in dairy products, 2011

(Millions of us dollars)

\begin{tabular}{l|r|r|r}
\hline Country & Exports & Imports & Balance \\
\hline Australia & 2,071 & 674 & 1,397 \\
\hline Brunei & n.a & n.a & n.a \\
\hline Canada & 286 & 601 & -315 \\
\hline Chile & 222 & 114 & 108 \\
\hline Japan & 21 & 1,806 & $-1,785$ \\
\hline Malaysia & 401 & 836 & -435 \\
\hline Mexico & 227 & 1,789 & $-1,562$ \\
\hline New Zealand & 10,112 & 103 & 10,009 \\
\hline Peru & 118 & 160 & -42 \\
\hline Singapore & 455 & 1,384 & -929 \\
\hline United States & 4,157 & 2,701 & 1,456 \\
\hline Vietnam & 97 & 503 & -406 \\
\hline Total TPP & 18,167 & 10,671 & 7,496 \\
\hline World Trade & 38,819 & 30,833 & 7,986 \\
\hline
\end{tabular}

Notes: n.a. $=$ not available a . Data for Vietnam are from 2010. Note: Dairy products refer to all goods in Harmonized Schedule 04 and 3501.

Source: adapted from Schott et al., 2013: 20.

\subsubsection{Criticisms about the TPP}

Some TPP critics said that the agreement will negatively affect participant members. Two of their arguments and contra arguments are presented next. First, the TPP is "going far beyond the realm of tariff reductions and trade promotion, granting unprecedented power to corporations and infringing upon consumer, labour, and environmental interests" (Nizami, 2013, para. 7). In this regard, Stephens \& Navarro (2014) pointed out that "critics of the TPP complain that the agreement is intrusive [...] but trade agreements moved beyond simple tariff reductions and customs procedures years ago"; thus the opportunities and challenges are to regulate about new issues that move forward TPP economies (p. 3).

A second criticism is that the TPP is pursuing geopolitical objectives and is part of a US political strategy (Petri \& Plummer 2012:2). About this, Petri \& Plummer (2012) mentioned that TPP could have political issues in play, 
but the most important issue is to decide based on objective data, and in this regard, there are economic calculations which suggest that the TPP would benefit all the participant nations (Petri \& Plummer 2012:2).

\subsubsection{The TPP, APEC and the WTO}

Kuriyama (2011) noted that the close relationship between the TPP and the Asia-Pacific Economic Cooperation forum (APEC) through the declaration of APEC leaders in 2010: "We will take concrete steps toward realization of a Free Trade Area of the Asia Pacific (FTAAP) [...] by developing and building on ongoing regional undertakings, such as ASEAN +3 , ASEAN +6 , and the Trans-Pacific Partnership,-15 among others" (p. 25). Likewise, Dawson (2012) reported that "the TPP expansion plan is to include APEC countries in successive clusters that will eventually encompass more than half of global output and over 40 percent of world trade" (p. 3).

On the other hand, Schott et al. (2013) pointed out that "with the Doha Round of multilateral trade negotiations at an impasse, the Trans-Pacific Partnership (TPP) has taken center stage as the most significant trade initiative of the 21 ${ }^{\text {st }}$ Century" (p. 1). Thus, Fergusson et al. (2014) mentioned that there are people who trust that the TPP could support the "WTO goal of greater global trade liberalization" through the setting of new standards (p. 6).

\subsection{Economic impact}

Petri et al. (2012) recognized that there could be several factors considered to decide the participation from one nation in a FTA, but the economic benefits should be one of the most important criteria and in that way, they concluded that economic impact "strongly favours" becoming a member of the TPP (p. 87). In this section, information is provided to foresee the economic impact of the TPP.

\subsubsection{Indicators}

According to Schott et al. (2013), the 12 TPP partners are "remarkably diverse" with regard to their economic structure, including their international trade (p. 6). 
The Trans-Pacific Partnership: Understanding the Economic Impact for Mexico and Canada

Table 6

Imports and exports value, 2013

(Million USD)

\begin{tabular}{l|r|r|r|r}
\hline TPP nations & $\begin{array}{c}\text { Merchandise } \\
\text { exports }\end{array}$ & $\begin{array}{c}\text { Merchandise } \\
\text { imports }\end{array}$ & $\begin{array}{c}\text { Commercial } \\
\text { services exports }\end{array}$ & $\begin{array}{c}\text { Commercial } \\
\text { services imports }\end{array}$ \\
\hline Australia & 252,665 & 242,132 & 52,247 & 62,211 \\
\hline Brunei & 11,448 & 3,612 & 1,209 & 1,546 \\
\hline Canada & 458,379 & 474,270 & 78,162 & 104,865 \\
\hline Chile & 76,684 & 79,178 & 12,660 & 15,335 \\
\hline Japan & 715,097 & 833,166 & 145,356 & 162,287 \\
\hline Malaysia & 228,276 & 206,014 & 39,834 & 45,045 \\
\hline Mexico & 380,189 & 390,965 & 19,586 & 28,803 \\
\hline New Zealand & 39,445 & 39,641 & 13,067 & 12,212 \\
\hline Peru & 42,177 & 43,670 & 5,929 & 7,512 \\
\hline Singapore & 410,250 & 373,016 & 122,137 & 128,430 \\
\hline United States & $1,579,593$ & $2,329,060$ & 662,041 & 431,524 \\
\hline Vietnam & 132,033 & 132,033 & 10,380 & 13,015 \\
\hline Total TPP 12 & $4,326,235$ & $5,146,757$ & $1,162,608$ & $1,012,785$ \\
\hline World Trade & $18,826,000$ & $18,904,000$ & $4,644,380$ & $4,381,350$ \\
\hline TPP-12 / World (\%) & 23 & & & 25 \\
\hline Source: & & 27 & 23 \\
\hline
\end{tabular}

Source: elaborated by author with data source from statistics of the World Trade Organization (พто).

Table 7

Rank in world trade, 2013

\begin{tabular}{l|l|l|l|l}
\hline TPP nations & \multicolumn{1}{|c|}{$\begin{array}{c}\text { Merchandise } \\
\text { exports }\end{array}$} & $\begin{array}{c}\text { Merchandise } \\
\text { exports }\end{array}$ & $\begin{array}{c}\text { Commercial } \\
\text { services exports }\end{array}$ & $\begin{array}{c}\text { Commercial } \\
\text { services imports }\end{array}$ \\
\hline Australia & 21 & 23 & 25 & 19 \\
\hline Brunei & 88 & 139 & 121 & 120 \\
\hline Canada & 13 & 11 & 17 & 14 \\
\hline Chile & 47 & 38 & 50 & 48 \\
\hline Japan & 4 & 4 & 8 & 6 \\
\hline Malaysia & 25 & 24 & 30 & 28 \\
\hline Mexico & 15 & 14 & 41 & 34 \\
\hline New Zealand & 60 & 60 & 48 & 55 \\
\hline Peru & 59 & 58 & 68 & 64 \\
\hline Singapore & 14 & 15 & 12 & 7 \\
\hline United States & 2 & 1 & 1 & 1 \\
\hline Vietnam & 34 & 32 & 54 & 54 \\
\hline
\end{tabular}

Source: elaborated by author with data source from statistics of the World Trade Organization (พто). 
Seen as a group, Dawson \& Bartucci (2013) highlighted three important data about the TPP12. First, it represents a trading area of more than 800 million consumers; second, TPP12 includes two out three most important economies around the globe (United States and Japan); and third, the median age of the population is around 34 years old (p. 2-4).

Figure 1

Population (millions) of TPP states, 2015

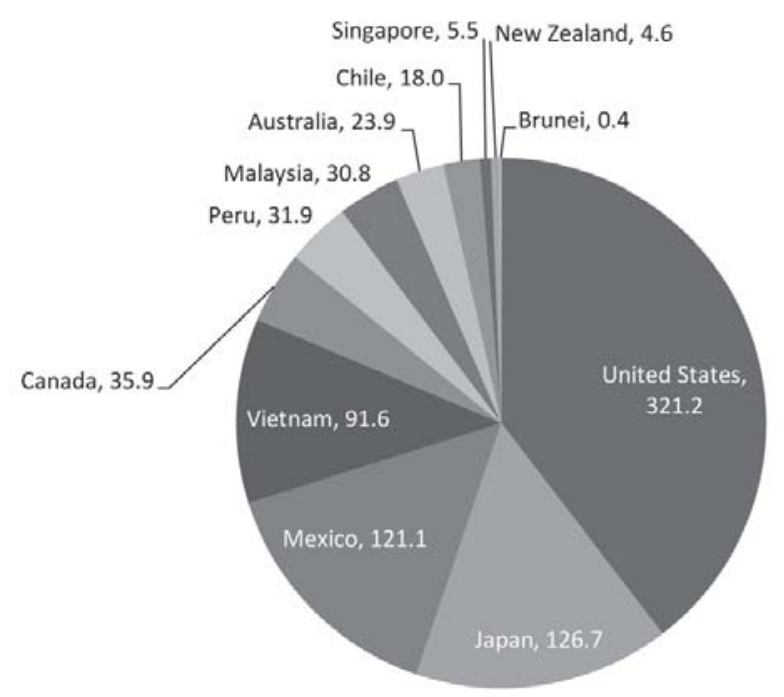

Source: elaborated by author with data source from IMF World Economic Outlook, April 2015.

Figure 2

Median age of population of TPP states, 2015

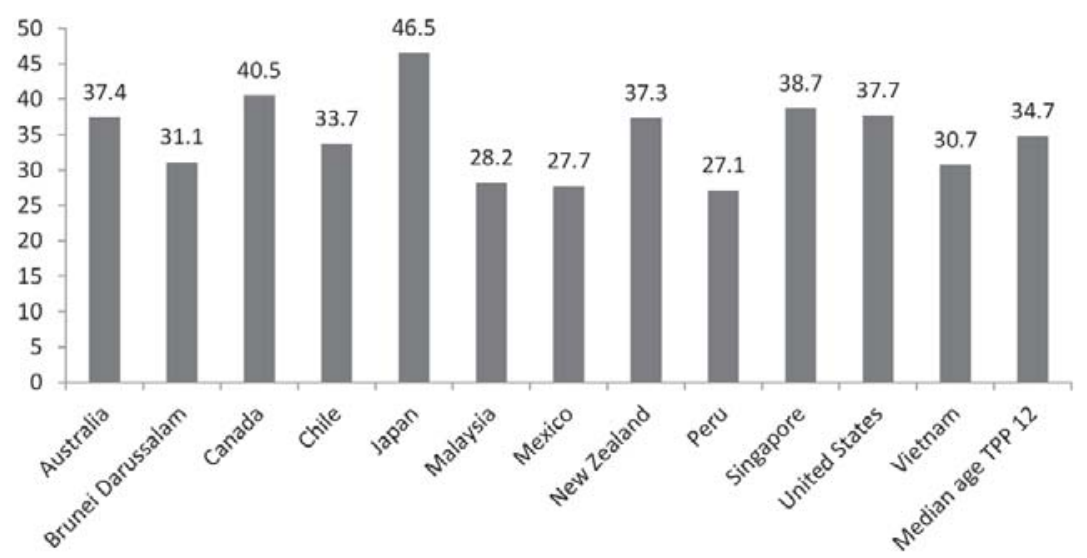

Source: elaborated by author with data source from United Nations, Department of Economic and Social Affairs, Population Division (2015). 


\subsubsection{Trade creation and trade diversion}

To evaluate the net benefits from any FTA, the concepts of trade creation and trade diversion are useful. According to Qwang (2014), trade creation is when "free trade, utilizing the comparative advantage of each member country, will benefit national welfare", whereas trade diversion is "when a member [nation] switches import from an efficient country to a less efficient country due to the FTA" (para. 3). Petri et al. (2012) added that "trade diversion harms both the importer, which now pays more (net of tariffs), and the exporter, which suffers deterioration in its terms of trade, leading to wider welfare losses" (p. 60). Qwang (2014) affirmed that the goal of any trade agreement "should always be maximizing trade creation or minimizing trade diversion" (para. 4).

Deardorff (2014) underlined that when a nation was outside of one trade agreement and becomes a member of it, this country will gain economic benefits, one of them to reverse the trade diversion (p. 11). Trade reversion appears when commerce is shifted from a more efficient exporter towards a less efficient one for the creation of a FTA (Petri et al., 2012: 60). In this regard, Messerlin (2013) foresaw that TPP would produce benefits for all the members but could damage the nations outside of it. Messerlin (2013) offered the reasons why this would happen: "the initial protection of the TPP countries [and] the TPP negotiating ability to implement a 'deep' liberalization, for example the wide opening of services markets and the long term competition dynamics" (p. 291).

Magee (2008) noted that depending on the kind of trade pact signed, the results about trade creation or trade diversion would be different, and it would impact the "overall trade effect and the time path of trade effects" (p. 350). Thus, Petri \& Plummer (2012) estimated that because of its objectives

and scope, the TPP would bring economic gains for all and that "these benefits are mainly the result of trade creation" (p. 8).

\subsubsection{Economic estimations}

Guoqiang \& Petri (2014) concluded: "the economic benefits from this 12-party agreement are likely to be substantial" (p. 20). Pham et al. (2014) affirmed that "the conclusion of the TPP would create the most important free trade zone in the world" (p. 3). Petri et al. (2012) estimated some economic scenarios, and they concluded that all the nations involved in this FTA would receive 
economic gains based mainly on trade creation and that "by 2025, the TPP track would yield global annual benefits of $\$ 295$ billion" (p. 35). About Mexico and Canada, Petri et al. (2012) observed that Mexico would "benefit substantially" from TPP gaining 21 billion in additional incomes and they estimated that Canada would receive 9.9 billion in additional economic benefit (p. 41).

Table 8

GDP and income gains in 2025 as result of the TPP

(Billions of 2007 dollars)

\begin{tabular}{l|r|r|c|}
\hline TPP nations & GDP & Income gains & $\begin{array}{c}\text { Percent change } \\
\text { from base line }\end{array}$ \\
\hline Australia & 1,433 & 8.6 & 0.6 \\
\hline Brunei & 20 & 0.2 & 1.1 \\
\hline Canada & 1,978 & 9.9 & 0.5 \\
\hline Chile & 292 & 2.6 & 0.9 \\
\hline Japan & 5,338 & 119.4 & 2.2 \\
\hline Malaysia & 431 & 26.3 & 6.1 \\
\hline Mexico & 2,004 & 21.0 & 1.0 \\
\hline New Zealand & 201 & 4.5 & 2.2 \\
\hline Peru & 320 & 4.5 & 1.4 \\
\hline Singapore & 415 & 8.1 & 2.0 \\
\hline United States & 20,773 & 77.5 & 0.4 \\
\hline Vietnam & 340 & 46.1 & 13.6 \\
\hline Total TPP 12 & 33,545 & 328.7 & - \\
\hline World Trade & 103,223 & 294.7 & 0.3 \\
\hline
\end{tabular}

Source: adapted by author from Petri et al., 2012: 41-42.

About exports, Petri et al. (2012) estimated that TPP exports by 2025 would reach 444 billion globally (p. 43). Specifically, Petri et al. (2012) showed that Mexico and Canada would increase their exports through this FTA in 31.5 and 15.7 billion (p. 44), respectively.

Pham et al. (2014) provided some numbers about exports, but just focused on the spillover effects that standards in IPRs could spread through US companies and their subsidiaries in TPP nations. They concluded that:

The formation of TPP will boost U. S. annual exports by between $\$ 20.6$ and $\$ 26.2$ billion, will contribute between $\$ 9.0$ and $\$ 11.3$ billion to U. S. GDP, and will create between 38,811 and 47,586 jobs. The spillover effects of U. S. companies' exports 
The Trans-Pacific Partnership: Understanding the Economic Impact for Mexico and Canada

to their foreign affiliates in the other 11 TPP countries are more than $\$ 26.9$ billion in additional sales, $\$ 6.4$ billion in additional GDP, and 68,240 jobs (p. 5).

Table 9

Exports and exports increases in 2025 as result of the TPP

(Billions of 2007 dollars)

\begin{tabular}{l|r|r|c|}
\hline TPP nations & Exports, 2025 & Export increases & $\begin{array}{c}\text { Percent change } \\
\text { from base line }\end{array}$ \\
\hline Australia & 332 & 14.9 & 4.5 \\
\hline Brunei & 9 & 0.3 & 2.8 \\
\hline Canada & 597 & 15.7 & 2.6 \\
\hline Chile & 151 & 3.8 & 2.5 \\
\hline Japan & 1,252 & 175.7 & 14.0 \\
\hline Malaysia & 336 & 41.7 & 12.4 \\
\hline Mexico & 507 & 31.5 & 6.2 \\
\hline New Zealand & 60 & 4.7 & 7.8 \\
\hline Peru & 95 & 6.7 & 7.1 \\
\hline Singapore & 263 & 11.0 & 4.2 \\
\hline United States & 2,813 & 124.2 & 4.4 \\
\hline Vietnam & 239 & 89.1 & 37.3 \\
\hline Total TPP 12 & 6,654 & 519.3 & - \\
\hline World Trade & 28,415 & 443.7 & 1.6 \\
\hline
\end{tabular}

Source: adapted by author from Petri et al., 2012: 44-45.

Finally, Williams (2013) showed the economic benefits that all TPP nations could achieve through a higher liberalization of their markets and reduction of trade barriers (p. 25-29). Williams (2013) identified the products with the highest tariffs for each TPP nation. This list included products such as clothing, dairy, sugar, and electrical machinery (p. 25).

Finally, it's important to make note that Petri et al. (2012) considered that the TPP is one real option to create the Free Trade Area of the Asia Pacific (FTAAP), and they added that the FTAAP could be reached in 2020 (p. 28). Petri et al. (2012) predicted that with the income gains, by 2025 the FTAAP would generate for the participants 1,922 billion (p. 35) and they estimated that FTAAP would increase world exports by $\$ 3.3$ trillion (p. 45). 
Table 10

Highest tariffs by product category in TPP nations

(Tariffs in percent, 2011)

\begin{tabular}{llc}
\hline \multicolumn{1}{c}{ Country } & \multicolumn{1}{c}{ Product } & Avg. Applied MFN Tariff (\%) \\
\hline Australia & Clothing & 8.9 \\
Brunei & Electrical machinery & 13.9 \\
Canada & Dairy Products & 246.8 \\
Chile & Most Products & 6.0 \\
Japan & Dairy Products & 178.5 \\
Malaysia & Beverages and tobacco & 119.7 \\
Mexico & Sugars and confectionery & 59.3 \\
New Zealand & Clothing & 9.6 \\
Peru & Clothing & 13.0 \\
Singapore & Beverages and tobacco & 2.4 \\
United States & Dairy & 19.1 \\
Vietnam & Beverages and tobacco & 43.6 \\
\hline
\end{tabular}

Source: Williams, 2013: 25.

\section{Analysis}

The analysis section is grouped in the following themes: the objectives and scope of the TPP, its issues, the economic gains, the TPP members, Mexico and Canada, and finally, understanding and using the TPP.

\subsection{Objectives and scope of the TPP}

The TPP nations' goal is to have a modern, unique and innovative FTA. While this appears very ambitious and challenging, this goal could be achieved if TPP negotiators continue to focus on the objectives of creating a comprehensive agreement and next generation regional FTA. Part of these objectives include having a living agreement, liberalizing trade and investments, giving solutions to traditional and non-traditional issues in the international trade and integrating these 12 nations into an agreement.

As a result, the objectives and the scope are helping to increase the liberalization of the global trade that the WTO has been seeking, but unable to achieve, for decades. This liberalization could be possible through the TPP. The 
TPP might be able to liberalize global markets through the sum of regional FTAs. In this regard, the TPP is considered an important piece to build the FTAAP. Thus, being a TPP member represents a unique opportunity due to the impact that it could have in the regional and global economy.

\subsection{Issues}

Discussing both traditional and non-traditional issues has added value and positive expectations among the stakeholders of the TPP. Addressing issues that were forbidden before, such as competition policies, market access, intellectual property rights (IPRs), labour, and the environment are positive signs. Studies such as the impact that new IPR standards could generate through spillover effects through us companies and their subsidiaries in TPP nations are very encouraging. As was shown in the literature review, the implementation of standards related to IPRs would increase the GDP, jobs and sales in all the TPP nations. These findings demonstrated how agreement on one issue, such as the IPRs, could create positive economic impact for all the TPP members.

Though many people are waiting for an agreement on the final text as soon as possible, it is better to spend more time until all the issues have been fully discussed and agreed upon by all parties. If the members are pressured to sign the deal, it could create a FTA similar to others that have several "sensitive sectors" excluded. In the past, the negotiations of FTAs have included these "sensitive sectors" through which nations have protected some products, for example rice in Japan, dairy in Canada, and sugar in Mexico. This approach has reduced the economic benefits that FTAs could produce if they opened the discussions to all products. The TPP members should avoid falling into this temptation because it would affect the economic impact of the agreement. 
In the particular case of Canada, many people have expressed concerns about the dairy industry; however research found that including the dairy industry in the TPP would not be catastrophic if Canada accepted decreasing its protection about dairy products. Actually, the TPP would provide an opportunity to change the model from a protectionist industry to an exporter industry. For instance, Canada could export dairy products to Japan which, in 2011, imported 1.8 billion. Additionally it could export to Vietnam which imported approximately 500 million in 2011, or other Asian markets.

Mexico should apply the same logic, creating new opportunities for strategic sectors based on the issues and trade-offs. For example, if Mexico accepted reducing some tariffs in agricultural products such as sugar, it could request that Vietnam decrease its tariffs on beverages and tobacco, which are quite high. Additionally it could negotiate with Brunei to reduce its tariffs in electrical machinery. In brief, discussing the issues is a great opportunity to negotiate and create trade-offs among TPP members, adding real value in comparison with FTAs from the past.

\subsection{Economic gains}

Research has shown that the TPP is a trade pact that would generate economic gains for all 12 participating nations. One of the most important findings reported that world trade could gain 295 USD billion by 2025 in additional incomes through the TPP. In this regard, Mexico and Canada could generate additional incomes equal to 21 and 9.9 usD billion, respectively.

As well, the research showed the positive estimation of the impact that TPP would generate in spillover effects through US companies and their branches in the TPP just through the implementation of standards in the IPRs. This study concluded that the TPP would boost jobs, GDP and exports in all the TPP nations. Due to the integration of Canada and Mexico with the US market through NAFTA, these estimations seem to state implicitly that both nations have a good chance to get higher benefits from the spillover effects. For instance, in the creative industries where the IPRs are very important and where Canada and Mexico have companies, they could work together with the United States to improve their level of integration and generate this kind of spillover effect. This is one of the reasons why Canada and Mexico joined the TPP, to avoid losing their advantage in the US market and to keep their advantages in NAFTA. 
In addition to the benefits that the TPP could generate directly, the TPP is an investment in the medium term because it represents the entrance to participate in even bigger FTAs such as the FTAAP that, according to the literature review might be a reality in 2020 . So, the economic benefits that TPP would offer for both Mexico and Canada support the decision that they took to be part of this FTA, because the TPP would create not only direct benefits, but also new benefits through the integration with other nations in the future.

It's important to underline that Mexico would be one of the most favoured nations of the TPP based on the additional income that could be produced through this FTA. For that reason, the Mexican private sector should get involved in the TPP negotiations with positive feedback for authorities to avoid losing this opportunity. Likewise, the economic outlook for Canada is promising; reason enough to support its participation.

In addition to the positive calculations, another positive aspect of the TPP is that it is expected to produce trade creation. Trade creation would be true for the new trade relationships among countries that previously did not have FTAs among them. In particular, Mexico and Canada would gain access to six new nations: Australia, Brunei, Malaysia, New Zealand, Singapore and Vietnam; additionally, Canada would gain access to Japan. For both countries there is opportunity to open new and key markets where they previously did not have any FTAs through the TPP. Nonetheless, trade creation would not only occur from the new trade relationships that TPP nations would start, but also for relationships with nations that already have bilateral FTAs. It means that the TPP could have the capacity to increase the current level of commerce and investment among nations that currently have FTAs. The TPP could create greater trade liberalization commitments than existing FTAs, so there would still be additional advantages even for those countries with existing bilateral FTAs.

\subsection{TPP members}

All 12 countries in the TPP are like-minded and share the belief that they can create a comprehensive FTA which creates new standards in global trade. Further, all the TPP nations have special features that add value and potential to the group, and they also have differences that complement each other. For example, Canada could take advantage of the average age of people in countries of the TPP12, which is around 34 years old. In this regard, Canada 
could improve its demographic bonus through the openness of their labour market for some strategic industries where they need young people, especially considering that Canada's population is aging. The median age of the population in Canada is around 40 years old, whereas in countries such as Malaysia and Mexico, the median age is about 28 years old. Considering this same information, Canada might offer the expertise of their people in Mexico and Malaysia, where they have a younger population.

\subsection{Mexico and Canada}

Mexico and Canada should work even closer together on different initiatives, including the TPP. These two nations have undertaken some strategies together during the TPP and in the past, but the potential and the conditions to collaborate exist even more for these two nations. Thus, one of the most important challenges to promote in the Mexican-Canadian relationship is to boost discussions about bilateral projects and initiatives. In addition, the trade relationship and collaboration among these two nations could be increased because of the close geographic distance makes it easy to move products, NAFTA makes doing business easier, and their complementary sectors that could work together.

About creating synergies and collaborations among Mexico and Canada, some examples of the industries that could be more integrated are the automotive, mining, advanced manufacturing, IT, education, energy, aerospace, agricultural, energy, and services including banks and insurance companies. Some examples of the most emblematic Canadian companies in Mexico are Bombardier, Goldcorp and Scotia Bank, and some Mexican companies in Canada are Alfa Group, Eumex and Mabe; however, these are large companies. The opportunities and challenges are promoting collaboration even in the small and medium enterprises (SMEs) from both nations, because they represent the largest percentage of businesses. Thus, the Canadian and Mexican business people could promote these kinds of collaborations, regardless of the size of their companies.

\subsection{Understanding and using the TPP}

Many business people are not aware of the existence of the TPP negotiations, and this lack of knowledge could put the future of their businesses at risk. 
Some of them underestimate the real economic value of the TPP. The TPP is a transcendental FTA that might change the classic route that FTAs have followed until now. The important part of this research project found economic calculations and evidence that showed the economic benefits that the TPP would produce. These findings are very promising for the Asia-Pacific region, including the two countries that this document has focused on, Mexico and Canada. The good economic estimations for the TPP should give leaders from the private sector confidence and encouragement to learn more about the agreement.

Canadian and Mexican business people have the responsibility of preparing themselves to use the TPP as soon as it is in force. For example, many companies in Mexico and Canada currently enjoy the benefits of NAFTA, but many others continue without taking full advantage of NAFTA, even though it has been in existence for more than 20 years. The TPP should be used to its maximum capacity by private sector to gain all the benefits created for their nations and businesses.

\section{Recommendations}

From the analysis section emerged seven recommendations to be implemented by Canadian and Mexican business people.

\subsection{Knowing and learning more}

Canadian and Mexican Business people have to continue learning more about the TPP, to read more about topics that interest them related to the TPP, and to try to find answers to the questions that this research has generated. This recommendation includes keeping up-to-date about the next meetings of the TPP that will be decisive.

\subsection{Promoting the understanding of the impact of the TPP}

The recommendation to Business people is promote the objectives and scope that the TPP offers in the networks around them; in this way, they could help to clarify what the real purpose of the TPP is to other businesses and leaders in their network. This action includes that they should spread the word about the positive economic impact which TPP would produce in all the TPP12 countries. 
Canadian and Mexican business people should emphasise the economic benefits that their countries could gain through participation in the TPP. As well, it is important to highlight that the TPP is an agreement based on trade creation generated from two circumstances: the higher trade among TPP nations that already have existing FTAs and the new trade that would be created among TPP nations without existing FTAs.

\subsection{Encouraging dealing with and overcoming issues}

As was explained before, part of the economic benefits would be created through discussions and agreements about several issues for which each TPP nation could have different opinions. Thus, the recommendation is that the Business people encourage their governments to negotiate and spend time preparing and creating solutions to overcome these issues, including the sensitive sectors where they should use these as a tool to negotiate and create trade-offs among TPP members.

\subsection{Preparing to compete}

Business people should prepare themselves and their businesses to compete in the TPP. The TPP nations are ready to increase the liberalization of their economies; however, each business also needs to do its own part to be ready for more open trading with other TPP countries. Thus, the private sector should understand that they need to prepare in advance, including possibly developing new skills in their work teams, infrastructure and, overall, their businesses.

This recommendation includes that businesses generate their own information with regard to the TPP nations, analyzing their economic and business environment. The Canadian and Mexican companies should create their own scenarios, studies and information to guarantee that the TPP would really mean new opportunities for their businesses.

\subsection{Identifying collaborations between Mexico and Canada}

The recommendation for Business people from Mexico and Canada is to explore the feasibility and convenience of creating collaborations and synergies between companies from both sides, and building capacities together. They 
should take advantage of the experience that they might add together, regardless of the sector and size of their businesses. Through this recommendation, they might strengthen their supply chains each other in the TPP.

\section{Conclusion}

The TPP composed of 12 countries from the Asia-Pacific region: New Zealand, Peru, Vietnam, Australia, Singapore, Brunei, Malaysia, Mexico, Chile, Canada, Japan and the United States, could be a very unique FTA due its objectives, scope and the estimated positive economic benefits. Economists calculated that by 2025, the TPP might reach additional global incomes equal to 295 billion USD (Petri et al., 2012: 85). The TPP nations are like-minded and share the belief that they can create a comprehensive FTA which creates new standards in global trade. They are pursuing the solution to traditional and non-traditional trade issues through the creation of a next-generation FTA (Fergusson et al., 2014: 3).

Mexico and Canada have special opportunities to benefit from the TPP. There are several calculations that support their decision to become members of this FTA. It is estimated that Mexico could gain 21 billion USD in additional income by 2025, whereas Canada could receive 9.9 billion USD in extra income (Petri et al., 2012: 41-42). Other benefits are that they will increase their exports, GDP, jobs and opportunities to lever their economies. This means that both countries made the right decision to be part of this trade pact. For that reason, it is important for business people to become aware of the context and economic impact of the TPP.

Therefore, there are five recommendations for the Canadian and Mexican business people to increase their understanding and they get the benefits when this FTA is in force. These recommendations are to continue learning more about the TPP, to encourage the authorities negotiating this FTA to deal with and overcome the challenging issues, to promote the understanding of the positive impact that the TPP would produce, to preparing themselves and their businesses to compete, and to analyze potential collaborations between Canadian and Mexican businesses. If business people follow these recommendations, their lack of knowledge and understanding about this cutting-edge FTA would be reduced and their businesses would likely benefit when the TPP is signed, regardless the size of their companies. my 


\section{References}

Australian Government. (2012). Fifteenth round of Trans-Pacific Partnership Agreement (TPP) negotiations.

- - (2015). News Trans-Pacific Partnership Agreement meetings.

Beatty, P. \& Rozental, A. (2012). Forging a New Strategic Partnership between Canada and Mexico. The Centre for International Governance Innovation/ Canadian Chamber of Commerce.

Dawson, L. (2012). "Can Canada join the Trans-Pacific Partnership? Why just wanting it is not enough", Commentary - C. D. Howe Institute, No. 340, pp. 1-13.

- - (2014). Canada's trade with Mexico: Where we've been, where we're going and why it matters. The Canadian Council of Chief Executives.

Dawson, L. \& Bartucci, S. (2013). Canada and the Trans-Pacific Partnership: Entering a new era of strategic trade policy. Fraser Institute.

De Rosenzweig, F. (2012). México en el TPP: Una ventana hacia el futuro. International Centre for Trade and Sustainable Development (para. 33-34).

Deardorff, A. V. (2014). "Trade implications of the Trans-Pacific Partnership for ASEAN and other Asian countries", Asian Development Review, 31(2): 1-20.

Elms, D. K. (2013). “The Trans-Pacific Partnership Trade Negotiations: Some Outstanding Issues for the Final Stretch", Asian Journal of WTO \& International Health Law and Policy, 8(2): 379-599.

Fergusson, I., McMinimy, M. A. \& Williams, B. R. (2014). The Trans-Pacific Partnership (TPP) Negotiations and Issues for Congress. Congressional Research Service.

Foreign Affairs and International Trade Canada. (2015). Canada's Free Trade Agreements.

Foreign Affairs, Trade and Development Canada. (2012). Canada Formally Joins Trans-Pacific Partnership (Press release).

- - (2013). Benefits across Canada of a Trans-Pacific Partnership Agreement.

- - (2014a). Trans-Pacific Partnership (TPP) Free Trade Negotiations.

- - (2014b). Baird Marks 70 Years of Canada-Mexico Diplomatic Relations.

Government of Canada. (2014). Canada-Mexico Relations.

Guoqiang, T. \& Petri, P. A. (2014). New Directions in Asia-Pacific Economic Integration. East-West Center.

International Monetary Fund. (2015). World Economic Outlook. 
Kuriyama, C. (2011). "The Mutual Usefulness between APEC and TPP", APEC Policy Support Unit.

Magee, C. S. P. (2008). "New measures of trade creation and trade diversion", Journal of International Economics, 75(2): 349-362.

Messerlin, P. (2013). “The EU's strategy for Trans-Pacific Partnership”, Journal of Economic Integration, 28(2): 285-302.

Nizami, N. H. (2013, Sep 15). “Trans-Pacific Partnership: To join or not to join”, The Financial Express.

Petri, P. A. \& Plummer, M. G. (2012) The Trans-Pacific Partnership and Asia-Pacific Integration: Policy Implications. Peterson Institute for International Economics.

Petri, P. A., Plummer, M. G. \& Zhai, F. (2012). The Trans-Pacific Partnership and Asia-Pacific integration: A quantitative assessment. Washington, DC: Peterson Institute for International Economics.

Pham, N., Pelzman, J., Badlam, J. \& Sarda, A. (2014). "The economic benefits of intellectual property rights in the Trans-Pacific Partnership", NDP Analytics.

Promexico. (2014). Mexico-Canada Bilateral Relations.

Qwang, S. (2014). TPP brings more trade creation or trade diversion.

Rude, J. \& An, H. (2013). “Trans-Pacific Partnership: Implications for the Canadian industrial dairy sector", Canadian Public Policy, 39(3): 393.

Schott, J. J., Muir, J. \& Kotschwar, B. (2013). Understanding the Trans-Pacific Partnership. Peterson Institute for International Economics.

Secretaría de Economía. (2014). Acuerdo de Asociación Transpacífico (TPP).

Stephens, H. \& Navarro, J. (2014). "Mexico, Canada and the TPP: Common Issues, Common Concerns", Crossroads. Recovered from: https://crossroads.royalroads.ca/

The Japan Times. (2015, May 21). “TPP nations to give up on Guam ministerial meeting as TPA pends".

United Nations Development Programme. (2013). Human Development Index. United Nations. (2015). Department of Economic and Social Affairs, Population Division.

United States Trade Representative. (2014, June 16). Remarks by Ambassador Michael Froman at the Council on Foreign Relations: The Strategic Logic of Trade. Williams, B. R. (2013). Trans-Pacific Partnership (TPP) Countries: Comparative Trade and Economic Analysis. Congressional Research Service.

World Trade Organization. (2015). Trade profiles. 


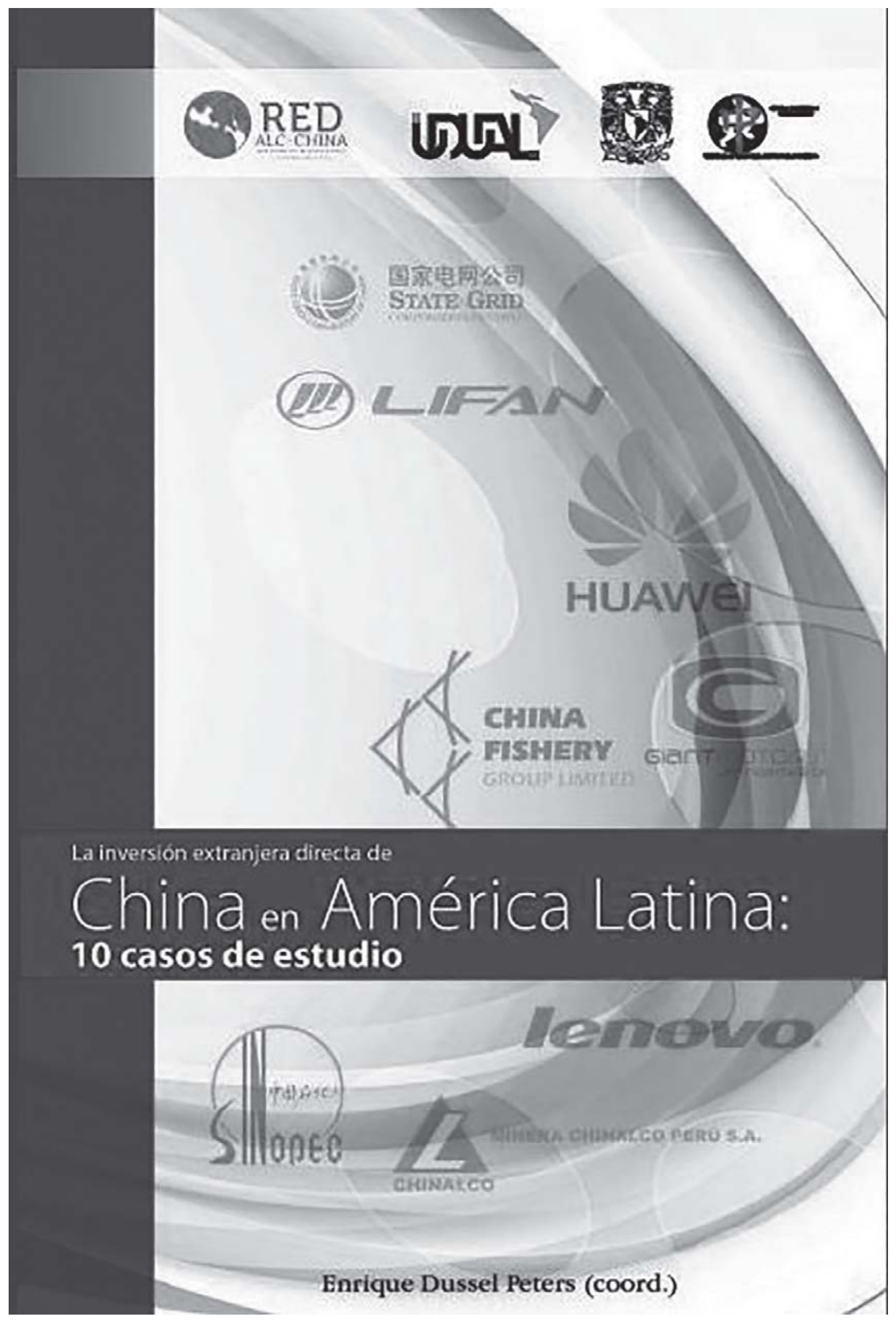

